\title{
Mediating Role of Affective Commitment in The Effect of Ethical Work Climate on Felt Obligation Among Public Officers
}

\author{
Hafid Aditya Pradesa *) \\ Joni Dawud **) \\ Muhamad Nur Affandi ***)
}

\begin{abstract}
Social exchange theory (SET) which explains the terms of the exchange agreement under the psychological contract assumes that what was promised is a key point in explaining individual responses at work. It was climate and support which will be argued as antecedents of individuals' attitudes and behaviors. Along with organizational support, ethical work climate was mostly examined only in relationship with intent-to leave. The purpose of this study was to determine felt obligation as the attitudinal outcome of ethical work climate, perceived organizational support, and affective commitment in terms of social exchange mechanism. This study is explanatory research based on primary data with a survey as the data gathered method. The result shows that one of five hypotheses rejected in this study. Furthermore, ethical work climate and perceived organizational support could affect felt obligation through affective commitment as mediation. Our findings are discussed below by considering the implications and limitations of this study.
\end{abstract}

Keywords: Ethical Work Climate; Perceived Organizational Support; Affective Commitment; Felt Obligation

\section{INTRODUCTION}

\subsection{Research Background}

Public organizations serve the role of providing public services, creating and implementing public policy. As a vital role in Indonesia development, change in public service has been underway for the past 20 years to improve government human resource systems. Public sector ethic goes to the heart of what public employees should do to fulfill their responsibilities as public officers. Every public officer serves within public sector organizations and endeavors to further the missions of his respective organizations. Functional missions such as safety and economic security were advanced by these officers. This would lead to highlight the achievements and tribulations of public officers who were empowered by their organizations to execute important duties.

Erakovich \& Wyman (2015) added that public organizations would be seen as a collective of individuals operating organization within a boundary that defines insiders and outsiders. Furthermore, public employees could operate within an integrated system and interrelated activities to accomplish a specific policy purpose while also reflecting on values of social equity, democracy, and responsiveness. Thus, the movement of public administration toward self-accountability suggests a need to consider internal organizational controls. This paper would serve as a healthy offset to the contemporary perspective of public officers in Indonesia as overpaid sluggards, sloths, and slackers. Based on a key question argued by Erakovich \& Wyman (2015) that: why do people in public organizations do things that they would never do by themselves? They believed that the organization is a place where people could work and are encouraged to socialization with other individuals and self-actualize through their motivation. Otherwise, it might be caused by a great 
sense of emotional attachment among individuals that will bring them to do the duty or job given by government authority.

As a paternalistic model still exist in the Indonesian public organization, it is urgently needed to avoid poor image (overpaid sluggards, sloths, etc.) of public officers in Indonesia by building great deal of sense of emotional attachment to the job (i.e. obligation, engagement) and organization (i.e. commitment), not only to the supervisors or leaders. This would be a great response among officers to foster their job performance that will positively contribute to organizational performance. It is not true when a public officer feels obligated only when the duties and personal intention collide with each other because the nature of this sense of obligation is natural to every person (Neblett, 1976). Coyle-Shapiro, Morrow, \& Kessler (2006) have demonstrated before; exchange can be linked to additional variance in individual obligation and fulfillment of obligation toward their organization. This implies the importance of felt obligation among public officers as a single outcome that must be enhanced by a public organization.

The main theoretical concept used in elaborating the individual felt an obligation in organizations is Social Exchange Theory (SET). This theory shows the classical assumption of "do ut des", that is, about the expression of the pattern that "I give something to you so that you also give something to me". The leading theoretical experts include psychologists such as Blau (1964) and Gouldner (1960). This exchange pattern exists and is embedded in the form of relationships between humans, both macro (group) and micro (interpersonal).

Felt obligation can be examined and enhanced through organizational support (Aselage \& Eisenberger, 2003), so that for ethical climate and affective commitment. Therefore, public officers will tend to have a different ethical climate perception with a different ethical orientation. By exploring ethical climate in the realm of government organizations, it will assist policymakers in understanding the nature of ethical conduct in their organizational setting and how these conditions might affect the implementation of public policy (Rasmussen, Malloy, \& Agarwal, 2003), and also individuals' attitude and behavior. Social exchange theory also explains about the terms of the exchange agreement under the psychological contract which assumes that the ability to deliver what was promised is a key point in explaining individual responses at work (Kasekende, Munene, Ntayi, \& Ahiauzu, 2015). Previous researchers (such as Huang, You, \& Tsai, 2012; Tsai \& Huang, 2008; Treviño, Butterfield, \& McCabe, 1998) obtain relevant empirical evidence to the issues on how ethical climate will lead to a higher form of commitment. In the context of this present study, it consists of a survey of public officers to address the relationships between ethical climate and perceived organizational support on affective commitment and felt obligation.

As previously stated, empirical research has considered the importance of organizational climate and support, which will be argued as antecedents of individuals' attitudes and behaviors. Similar with organizational support, ethical work climate was examined mostly in relationship with turnover intention (Treviño, Butterfield, \& McCabe, 1998; Schwepker Jr., 2001; Filipova, 2011; Abou Hashish, 2017), but still do not offer much insight into the theoretical underpinnings for examined felt obligation as attitudinal outcome in the social exchange perspective. In this article, we seek to address some of these challenges by examining the conceptual framework in public organization.

\subsection{Research Problem}

The social exchange theory (SET) suggested that perceived organizational support and affective commitment can prompt felt obligation. Social exchanges include assumptions of shared obligation and relationship in which participants perceive responsibilities to each other. Public organizations could utilize social exchange mechanism to manage their officers effectively. 
a) What is the relationship between perception of ethical work climate, perceived organizational support, and their affective commitment and felt obligation among public officers?

b) How do nurses perceived ethical work climate, perceived organizational support, affective commitment, and felt an obligation in their public organization?

\subsection{Research Purpose}

The purpose of this study is to determine felt obligation as the attitudinal outcome of ethical work climate, perceived organizational support and affective commitment in terms of social exchange mechanism. Focusing on ethical climate and organizational support is critical and complementary to individual attitudes in the organization. Thus, no previous study in the literature has investigated the effects of ethical work climate on individuals feeling about their obligation in an organization. In this study, we believe that there is a strong relationship between ethical work climate and perceived organizational support toward felt obligation both directly and indirectly through affective commitment.

\section{THEORETICAL FRAMEWORK AND HYPOTHESES DEVELOPMENT}

\subsection{The Relationship Between Ethical Work Climate and Perceived Organizational Support Toward Affective Commitment}

The organizational ethical climate is the shared behavior that directs organizational member ethical actions and decisions (Agarwal \& Malloy, 1999; Key 1999). These cumulative collections of shared practices are believed as observable and could affect public officers in the decisionmaking processes. Types of organizational ethical climates may influence types of ethical conflicts that arise and the process by which they are resolved. Ethical determinants and the level of ethical analysis can range from the individual to the broadest of social systems. The ethical climate is defined by Victor \& Cullen (1987) as "the shared behaviors of what is ethically correct and how ethical issues should be handled." Levels of ethical determinant refer to Kohlberg's theory of moral development and consist of egoistic, utilitarian, and principled levels.

Schwepker Jr. (2001) believed that ethical climate could affect work-related outcomes, in which commitment is recognized as an important one. This synthesis is enforced by Cullen, Parboteeah, \& Victor (2003) that prove an important relationship between ethical context (ethical climate dimension) with organizational commitment. Furthermore, Sharma \& Dar (2016) noted that commitment could be described by the affective commitment as the main component of the three elements. In this case, previous literature suggests that ethical climate can affect organizational commitment and specifically affective commitment. The apparent tendency to exaggerate individual affective commitment also does not seem surprising in behavioral research.

Individuals who perceived a strong perception of three ethical climate dimensions (rules and codes, service, caring) will develop an emotional attachment to their team (Dharmanegara, Pradesa, Tanjung, \& Harijanto, 2016). What is learned by acquiring knowledge about the effect of ethical work climate and level of Perceived Organizational Support (POS) and factors amenable for change in the work environment could help organizational leaders to deal effectively within dysfunctional behaviors and make a difference in enhancing individuals' dedication and loyalty to their organization. The ethical climate is believed to have more significant impact on individuals feeling toward their job and organization. Therefore, the first hypothesis proposed in this study is;

$\mathrm{H}_{1}$ : Ethical work climate will have a positive and significant effect on public officers affective commitment. 
POS is defined as individuals' belief that organization values their contributions and well being (Rhoades \& Eisenberger, 2002; Eisenberger, Fasolo, \& Davis-LaMastro, 1990; Eisenberger, Huntington, Hutchison, \& Sowa, 1986). As it is consistent with social exchange theory (Cropanzano \& Mitchell, 2005), it has been argued that there are significant existing relationships between POS and employee commitment (Rhoades \& Eisenberger, 2002). Furthermore, affective commitment (AC) denotes an emotional attachment to an organization, and it implies a vital position based on the fundamental meaning of commitment (Sharma \& Dhar, 2016). Many previous researchers have examined that commitment, which shows the focal point is affective commitment. Essentially, It is considered to be the most reliable predictor which results in employee retention (Allen \& Meyer, 1996). Strong empirical results have shown the great relationship between perceived organizational support and affective commitment (Rhoades \& Eisenberger, 2002 Aselage \& Eisenberger, 2003).

Based on previous empirical support, the next hypothesis proposed is;

$\mathrm{H}_{2}$ Perceived organizational support would have a positive and significant effect on public officers' affective commitment.

\subsection{The Relationship Between Ethical Work Climate, Perceived Organizational Support, and Affective Commitment Toward Felt Obligation}

Felt obligation is an individual prescriptive belief regarding whether they should care about the organization well-being and should help to reach organizational goals or not (Aselage \& Eisenberger, 2003). This implies that individual differences make employees react differently to perceived organization obligations and fulfillment of obligation and also contribute differently to the organization relationships with their employees (Ladebo, 2006).

In perceived organizational support (POS), there is a norm of reciprocity for outcomes which leads to a felt obligation to help organization, as well as the expectation that performance improvements are on behalf of the organization (e.g., Arshadi, 2011). Thus, felt obligation had been found positively arising from POS, and subsequently felt obligation is associated with affective commitment (Aselage \& Eisenberger, 2003). Coyle-Shapiro, Morrow, \& Kessler (2006) reinforced this empirical linkage (POS - felt obligation) on two different samples, i.e., contractors and clients. This empirical result suggested correlating felt obligation with antecedents such as organizational support and affective commitment.

Other previous researchers such as Ladebo (2006) and Shih \& Chen (2011) examined felt obligation that is not built based on the perspective of social exchange theory. Rasmussen, Malloy, \& Agarwal (2003) explored the concept of potential ethical climate by adding a useful dimension to our understanding of the complex relations between policy designers in government and policy implementers in the non-profit sector. A positive or strong ethical climate in an organization a necessary antecedent for behavioral and attitudinal outcomes is accepted, in which to a limited extent that would empirically be proven by researchers studying organizations (Victor \& Cullen, 1988). Previous scholars also have examined the relationship of felt obligation and affective commitment (Aselage \& Eisenberger, 2003; Coyle-Shapiro, Morrow, \& Kessler, 2006; Lew, 2009; Yew, 2011). Usually, the affective commitment would be examined as an outcome of felt obligation. Because of the high correlation identified in previous empirical result among that two variables (felt obligation - affective commitment), we argue that based on the norm of reciprocity, affective commitment could be determinant of felt obligation. 
Accordingly, the following hypotheses are proposed;

$\mathrm{H}_{3}$ : Ethical work climate will have a positive and significant effect on public officers felt obligation.

$\mathrm{H}_{4}$ : Perceived organizational support will have a positive and significant effect on public officers felt obligation.

$\mathrm{H}_{5}$ : Affective commitment will have a positive and significant effect on public officers felt obligation.

\section{RESEARCH METHOD}

\subsection{Research Design}

The study is explanatory research based on primary data, with a cross-sectional design that was used to survey public officers. The questionnaires were distributed by the researcher to officers who agreed to participate in the study. There are four main constructs measured in this study, i.e., ethical work climate, perceived organizational support, affective commitment, and felt an obligation. Each of the measures we used was adapted from scales that originally appeared in previous studies.

Confirmatory factor analysis (CFA) employed in this study to operate our variables, and to confirm latent constructs from responses to the survey questions. To confirm the total, direct, and indirect effects, a structural equation model (SEM; i.e., a measurement model with a path model) using the SmartPLS was employed to test the interrelationships between variables, and to assess the relative strength of each variable, and it utilized to test the research hypotheses. Results of simulation studies have shown that PLS analysis is appropriate when the sample size is small and is recommended in the early stage of theoretical development (Chin \& Newsted, 1999). The aim is to have a better understanding of the complex relationships between ethical work climate, perceived organizational support, and affective commitment and felt an obligation.

Ethical Climate Questionnaire (ECQ), which developed by Victor \& Cullen (1988) was used to measure public officers' perceptions of EC in their public organization. It consisted of five EC dimensions: instrumental, caring, independence, professional law and code, and rules. Responses were measured on a 5-point Likert scale ranging from "5" (completely true), to "1" (completely false). The higher mean of an ECQ dimension reflects a higher level of public officers' perception of it.

Survey of Perceived Organizational Support (POS) developed by Eisenberger, Huntington, Hutchison, \& Sowa (1986) is a 6-item scale used to measure public officers' perception of whether the organization appreciated their contributions and whether have treated them favorably or unfavorably in differing circumstances. Responses were measured on a 5-point Likert scale ranging from " 5 " (strongly agree), to " 1 " (strongly disagree). High mean indicates high organizational support perceived by public officers.

Survey of Affective Commitment adopted from Allen \& Meyer (1990). An adapted 5-item scale used to measure public officers' perception of affective personal state and emotional attachment to their organization. Responses were measured on a 5-point Likert scale ranging from "5" (strongly agree), to "1" (strongly disagree). High mean indicates public officers feel the high affective commitment.

Survey of Felt Obligation developed by Aselage \& Eisenberger (2003), in which adopted in this study to generate a 5-item scale used to measure public officers' perception of needs to reciprocate in some kind of attitudinal or behavioral form as they have valuing treatment from the 
organization. Responses were measured on a 5-point Likert scale ranging from "5" (strongly agree), to "1" (strongly disagree). High mean indicates a high obligation that is felt by public officers.

\subsection{Population and Sample}

All respondents are working at the government agency at the provincial level and willing to participate in the study. Convenience sampling used in this study that in the time about 42 officers were taken as a respondent in this study. The respondents of this study were public officers employed by the West Java Province, a regional government organization. The West Java provincial government should develop and implement resourceful techniques to remain effective while managing human resources. The nonprofit organization could make decisions that meet the perceived needs of the clientele yet do so without strictly adhering to governmental policy.

\subsection{Research Framework}

Above all, This study is guided by the conceptual framework developed by Filipova (2007, 2011) and enforced by Abou Hashish (2017) which proposed and examined the relationship between certain organizational variables (i.e. ethical work climate and POS) and mediating variable (i.e. employees' commitment) and a dependent variable (i.e. turnover intention). Dependent variable that examined in this study was felt an obligation as an outcome of ethical work climate, POS, and affective commitment.

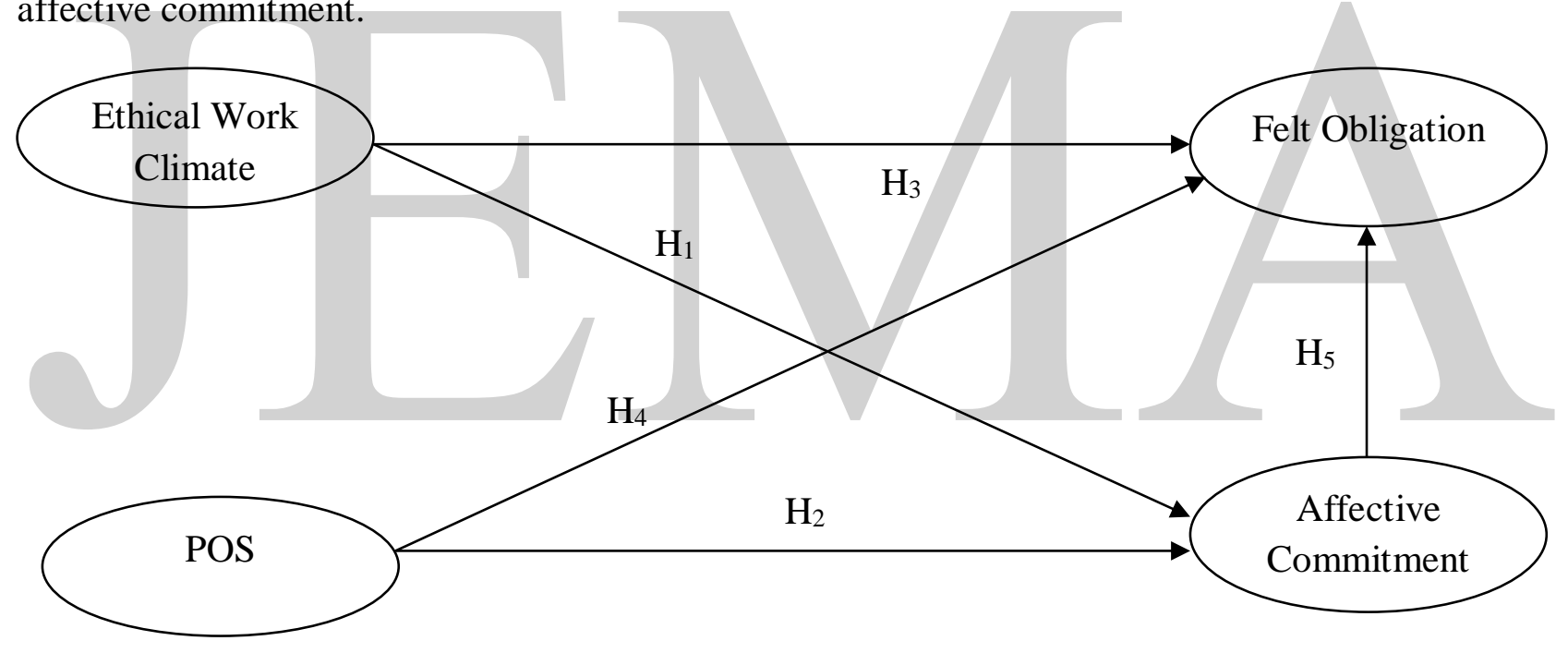

Picture 1 Research Framework

\section{RESEARCH RESULT AND ANALYSIS}

\subsection{Descriptive Analysis}

A majority of the respondents were male $(69,0 \%)$, from the 25-35-year-old age group $(50,0 \%)$, have a diploma level education $(35,7 \%)$. Only $9,5 \%$ among them are youngest age officers, and $31,0 \%$ hold a master degree as their educational background. Characteristics of respondents in the study are presented in the following table. 
JEMA: Jurnal Ilmiah Bidang Akuntansi dan Manajemen, Vol. 16 No. 2 (2019)

http://riset.unisma.ac.id/index.php/jema (e-ISSN : 2597-4071)

Table 1 Characteristics of Respondents

\begin{tabular}{|c|c|c|c|}
\hline Variable & Demographics & Frequency & Valid Percentage (\%) \\
\hline \multirow{2}{*}{ Gender } & Male & 29 & 69,0 \\
\cline { 2 - 4 } & Female & 13 & 31,0 \\
\hline \multirow{4}{*}{ Age } & $>25$ Years Old & 4 & 9,5 \\
\cline { 2 - 4 } & $25-35$ Years Old & 21 & 50,0 \\
\cline { 2 - 4 } & $35-45$ Years Old & 12 & 28,6 \\
\cline { 2 - 4 } & $>45$ Years Old & 5 & 11,9 \\
\hline \multirow{3}{*}{$\begin{array}{c}\text { Educational } \\
\text { Background }\end{array}$} & Diploma Degree & 15 & 35,7 \\
\cline { 2 - 4 } & Bachelor Degree & 14 & 33,3 \\
\cline { 2 - 4 } & Master Degree & 13 & 31,0 \\
\hline
\end{tabular}

Source: Primary Data Processed, 2018

\subsection{Validity and Reliability}

A confirmatory factor analysis (CFA) used to confirm latent constructs from the relevant survey questions. It also used for each of the latent variables to examine the validity of the measures. Standardized factor loadings are presented in Table 3. All of the factor loadings statistically are significant (p 0,001), with greater than the recommended loading value of 0,5 (Fornell \& Bookstein, 1982). By examining loading factors, findings reveal that ethical work climate was mainly manifested by service, while POS manifested by organization values officers' contribution, an affective commitment was primarily manifested by a strong sense of belonging of organization and felt obligation was primarily manifested by the personal obligation to ensure highquality product produced. Confirmatory factor analysis results show statistical evidence (as reported in Table 3) that each component construct of ethical work climate, perceived organizational support, affective commitment, and felt obligation are fits the data well. The fit statistics were within generally accepted ranges, indicating that our research model with affective commitment as a higher-order reflective construct (highest average of standardized factor loading compared with other variables).

Descriptive statistics for these independent variables, as well as the intervening and dependent variables in the structural model, are presented in Table 3. Caring is the highest mean of ethical work climate, while organization values officers' contribution is the highest mean of perceived organizational support. Affective commitment is more represented by the perception of working in a unit or team has a great deal of personal meaning among public officers. Personal obligation to ensure high-quality product produced and owe to give 100 percent energy represent the highest mean of felt obligation.

Table 3 shows descriptive statistics, scale reliability, and zero-order correlations between the variables. To test discriminant validity, the value of AVE in each factor was compared with and must exceed the squared correlations between that factor and all other factors. The means, standard deviations and correlations are also shown in Table 3 . The alpha reliabilities ranged from 0,855 to 0,931; these are all good reliability criteria and acceptable. Table 3 also present the correlations between the latent variables, with major correlations were highly statistically significant $(p<.001)$. 
JEMA: Jurnal Ilmiah Bidang Akuntansi dan Manajemen, Vol. 16 No. 2 (2019)

http://riset.unisma.ac.id/index.php/jema (e-ISSN : 2597-4071)

Table 3 Mean, Standard Deviation and Factor Loading

\begin{tabular}{|c|c|c|c|}
\hline & Mean & SD & Standardized Factor Loadings \\
\hline \multicolumn{4}{|l|}{ Ethical Work Climate } \\
\hline Caring & 3,93 & 0,894 & 0,676 \\
\hline Instrumental & 3,81 & 0,634 & 0,710 \\
\hline Independence & 3,71 & 0,918 & 0,841 \\
\hline Service & 3,71 & 1,043 & 0,867 \\
\hline Rules and Codes & 3,45 & 1,109 & 0,863 \\
\hline \multicolumn{4}{|l|}{ Perceived Organizational Support } \\
\hline The organization cares about my opinions & 3,43 & 1,039 & 0,901 \\
\hline The organization takes pride in accomplishments & 3,52 & 1,042 & 0,907 \\
\hline The organization values my contribution & 3,76 & 1,144 & 0,920 \\
\hline Organization appreciate any extra effort & 3,71 & 1,019 & 0,862 \\
\hline Organization care about the problem & 3,62 & 1,188 & 0,872 \\
\hline The organization cares about the well-being & 3,60 & 0,767 & 0,705 \\
\hline \multicolumn{4}{|l|}{ Affective Commitment } \\
\hline $\begin{array}{l}\text { Working in a unit or team has a great deal of } \\
\text { personal meaning }\end{array}$ & 3,69 & 0,869 & 0,828 \\
\hline Feel a strong sense of belonging of organization & 3,45 & 0,861 & 0,946 \\
\hline $\begin{array}{l}\text { Proud to tell others about working for an } \\
\text { organization }\end{array}$ & 3,67 & 1,028 & 0,861 \\
\hline Feel emotionally attached to an organization & 3,64 & 1,144 & 0,902 \\
\hline Feel caring about organization entirely & 3,43 & 1,172 & 0,885 \\
\hline \multicolumn{4}{|l|}{ Felt Obligation } \\
\hline $\begin{array}{l}\text { Feel personal obligation to help to achieve } \\
\text { organizational goals }\end{array}$ & 3,43 & 1,063 & 0,859 \\
\hline $\begin{array}{l}\text { Feel personal obligation to ensure high-quality } \\
\text { product produced }\end{array}$ & 3,52 & 1,110 & 0,940 \\
\hline $\begin{array}{l}\text { Feel obligation to take time from the personal } \\
\text { schedule }\end{array}$ & 3,45 & 1,131 & 0,920 \\
\hline Feel obligation to serve and satisfy others & 3,50 & 0,862 & 0,761 \\
\hline Feeling owe to give 100 percent energy & 3,52 & 1,018 & 0,831 \\
\hline
\end{tabular}

Source: Primary Data Processed, 2018

All the correlations among the variables in Table 3 were statistically significant and ranging from 0,80 to 0,89 . Interestingly, the correlation results indicate the strongest relationship between ethical work climate and felt an obligation. Ethical work climate was positively related to POS ( $\mathrm{r}=$ $0,800, \mathrm{p}=0,01)$, affective commitment $(\mathrm{r}=0,862, \mathrm{p}=0,01)$, and affective commitment $(\mathrm{r}=$ $0,899, \mathrm{p}=0,01)$. POS was positively related to affective commitment $(\mathrm{r}=0,888, \mathrm{p}=0,01)$, and felt obligation $(r=0,865, p=0,01)$. Also, the affective commitment was found to be positively related to the felt obligation $(r=0,891, p=0,01)$. In order to verify the reliability of each variable, internal consistency analysis was performed (as seen in Table 3). The Cronbach's $\alpha$ for all constructs was over 0,6 , which validates the reliability of the tool. Composite reliability for all constructs was over 0,8 , which validates high internal consistency among construct. 
JEMA: Jurnal Ilmiah Bidang Akuntansi dan Manajemen, Vol. 16 No. 2 (2019)

http://riset.unisma.ac.id/index.php/jema (e-ISSN : 2597-4071)

Table 3 Descriptive Statistic, Intercorrelations and PLS Quality Criteria

\begin{tabular}{|l|c|c|c|c|}
\cline { 2 - 5 } \multicolumn{1}{c|}{} & 1 & 2 & 3 & 4 \\
\hline 1.Ethical Work Climate & $(0,855)$ & & & \\
\hline 2. Perceived Organizational Support & $0,800^{* *}$ & $(0,931)$ & & \\
\hline 3. Affective Commitment & $0,862^{* *}$ & $0,888^{* *}$ & $(, 930)$ & \\
\hline 4. Felt Obligation & $0,899^{* *}$ & $0,865^{* *}$ & $0,891^{* *}$ & $(0,914)$ \\
\hline Mean & 3,724 & 3,607 & 3,576 & 3,486 \\
\hline Standard Deviation & 0,9196 & 1,0331 & 1,0148 & 1,1036 \\
\hline AVE & 0,632 & 0,747 & 0,783 & 0,748 \\
\hline Composite Reliability & 0,895 & 0,946 & 0,947 & 0,936 \\
\hline
\end{tabular}

Notes: **p , 0,01; *p , 0,05; Cronbach's alphas for each scale are italicised and shown in the diagonal.

Source: Primary Data Processed, 2018

\subsection{Research Analysis}

A structural equation modeling with Partial Least Square-based was estimated with four constructs: ethical work climate, perceived organizational support, affective commitment, and felt an obligation.

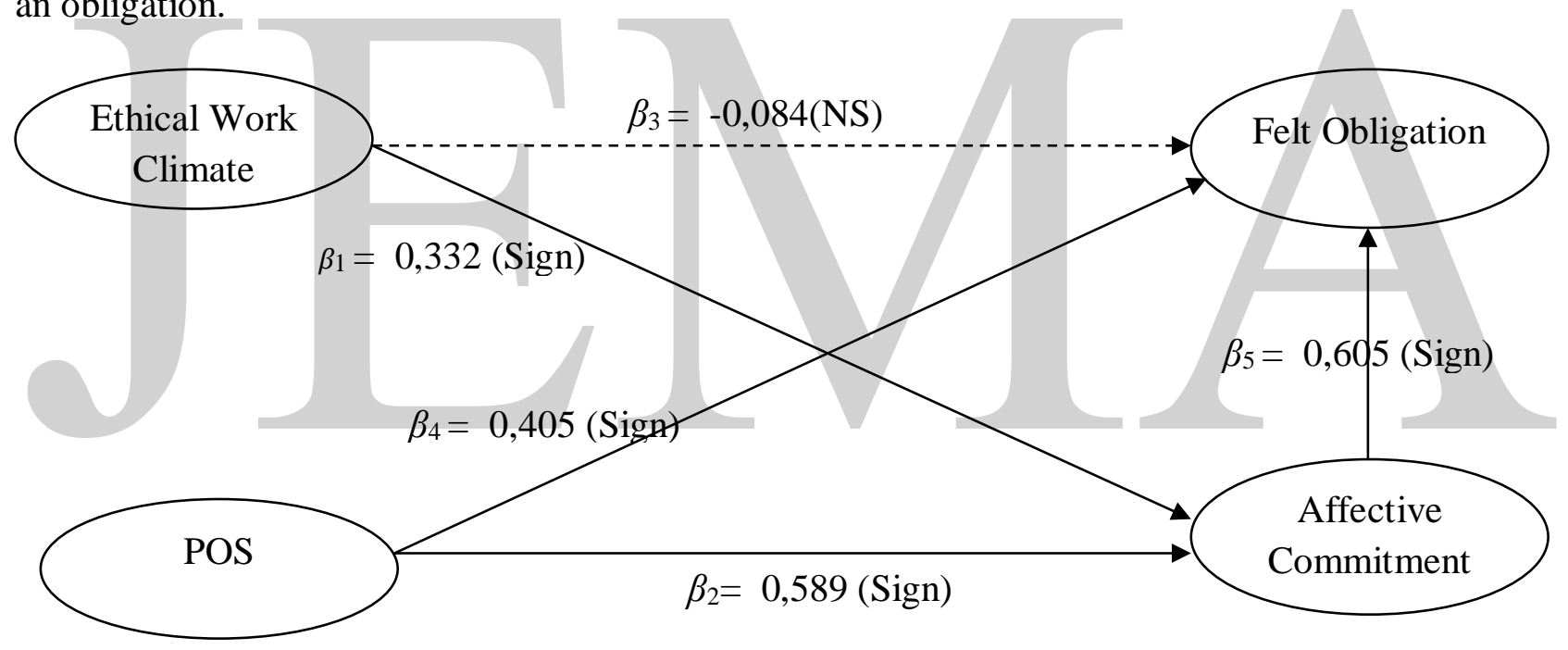

Picture 2 Result of Path Analysis

The results indicated that the $\mathrm{H}_{1}$ and $\mathrm{H}_{2}$ was supported, the public officers' perceptions of ethical work climate had a significant positive relationship with affective commitment $(0,332$, $\mathrm{p}<0,01$ and there was a significant and positive relationship between perceived organizational support $(0,589, \mathrm{p}<0,01)$. There was no empirical evidence of a significant relationship between ethical work climate and felt an obligation, $\mathrm{H}_{3}(\beta=-0,084, \mathrm{p}>0,05)$. While the path in a linear model of POS towards felt obligation $\left(\mathrm{H}_{4}\right)$ has a different result. A relatively moderate and positive effect was established between POS and felt obligation $(\beta=0,405, \mathrm{p}<0,01)$. Finding reveals higher POS will significantly increase public officers' felt obligation.

In testing $\mathrm{H}_{5}$, an affective commitment was associated with the felt obligation. The affective commitment had a significant positive effect on felt obligation $(\beta=0,605, \mathrm{p}<0,01)$. Therefore, the results provide support for $\mathrm{H}_{5}$. It is clear from the diagram (Picture 2) that the effects in this 
relationship (affective commitment - felt obligation) are the greatest effect compared with another in the model. This means affective commitment has the most important role in increasing public officers' felt obligation.

It is important to consider the mediating role of affective commitment on the relationship between ethical work climate and POS toward felt obligation. Affective commitment as the main component of organizational commitment would have an important role in fostering the effect of ethical climate and perceived organizational support.

a) Mediating effect of affective commitment on the effect of ethical work climate on the felt obligation

The calculation result shown beta coefficient of ethical work climate on felt obligation through affective commitment: $\beta_{1} \times \beta_{5}=0,332 \times 0,605=0,200$, The direct effect of ethical work climate to the felt obligation $\left(\beta_{3}\right)$ found was not significant. It can be concluded that affective commitment plays an important mediating role on the effect of ethical work climate on felt obligation.

b) Mediating effect of affective commitment on the effect of perceived organizational support on the felt obligation

The calculation result shown beta coefficient of POS on felt obligation through affective commitment : $\beta_{2} \times \beta_{5}=0,589 \times 0,605=0,356$. A direct effect of POS to the felt obligation $\left(\beta_{3}\right)$ found was 0,405 . It confirmed that affective commitment would play a partial mediating role in the effect of POS on felt obligation.

\subsection{Research Discussion}

While it has been generally assumed that nonprofitorganizations would make better partners for government because they are less likely to behave in an opportunistic manner, the results of this research indicate that leader in governments would be wise to exercise caution in their arrangements with the nonprofit sector especially in managing public officers. Ethical climate, in contrast, has been found to have only a weak or even sometimes a negative relationship with a specific attitudinal outcome such felt obligation. An understanding of ethical climate difference might well prove significant in dealing with social exchange mechanism, but it could not directly build felt obligation among public officers.

This study is one of a growing number to explore this interplay in terms of the conceptual framework advanced here. However, it is one of the very few to look at these concepts outside of the typical setting-specifically, in one of the province in Indonesia. The findings support one obvious general conclusion, not necessarily a surprising one-namely, that West Java provincial government officers do differ in interesting ways from public officers in Western cultures. This is demonstrated in particular by the strong effect of ethical climate as a predictor of affective commitment. The low and negative relationship between ethical work climate and felt obligation is also interesting and quite unusual.

Findings also show that in every relationship among variables are consistent with previous research. As stated earlier, ethical work climate (McManus \& Subramaniam, 2014; Tsai \& Huang, 2008; Schwepker Jr., 2001) and perceived organizational support (Lew, 2009; Yew, 2011) are important antecedents of affective commitment. But the main point is that finding also shows that for affective commitment in social exchange perspective, perceived organizational support is the most important predictor to building commitment (Eisenberger, Fasolo, \& Davis-LaMastro, 1990). However, recent studies show that ethical work climate, where not every positive work climate necessarily fosters felt obligation among public officers to the organization.

This seems to be an important consideration for the public officers examined here. However, research findings from West Java provincial government officers have shown that for the average 
officers, it is not enough to simply have a good climate in their organization and feel that they are supported by the organization; the terms of building emotional attachment are equally or even more important. It also seems that leader among public organization must concern and build more obligation among their public officers in the future.

\section{RESEARCH CONCLUSION AND LIMITATION}

\subsection{Conclusion}

The result of this study concluded that there is a positive significant correlation between public officer perception of overall ethical work climate and each of POS, affective commitment, as well as officers' felt obligation. However, the strongest relationship between ethical work climate and felt obligation shows contrary to its linear effect. No important and meaningful direct effect found in the relationship between ethical climate and felt obligation. Also, officers perceived a moderate ethical work climate, organizational support, affective commitment, as well as a felt obligation at their public organization. Public organization's administrator should emphasize organizational strategies for the provision of caring and supportive work climate to increase individual emotional attachment to the organization. Policies, policy processes, and institutional codes are recommended to raise the quality of ethical problem solving throughout the organization. For example, the administrator could establish a recognition/reward programs which considered an important strategy for increasing individuals feeling to be supported. The results of this study contribute to the theoretical understanding of the role of ethical work climate and perceived organizational support in contributing greater affective commitment and felt obligation among the public officers. The fact that EWC could not influence felt obligation directly, employees' affective commitment could play a perfect mediating role in the relationship between EWC toward felt obligation. One plausible explanation of this finding was that in social exchange context, people must feel emotionally attached before they could feel their obligation towards the organization. Another practical implication when comparing with ethical work climate, perceived organizational support has more powerful influence on individual attitudes (felt obligation), which in the long run will stimulate productive behaviors that contribute to organizational success.

\subsection{Limitation}

The current study used a cross-sectional design; also, it is relied on self-reporting measures, in which these mention limitations. Another limitation is relatively small sampling that truly not enough for generalization of findings. Future studies need to be replicated in a greater and bigger sampling for more generalization. Therefore, it would be recommended in a longitudinal design so that more appropriate to explore the causal relationship between predictive and criterion variables. Suggestion for future research is to understand how felt obligation is formed and determined. There is a particular need for further research investigating the role played by felt obligation and another component of attitudinal mechanism (i.e., normative commitment). Although both constructs may be different in the same phenomenon, empirical findings are needed to demonstrate their impact on individual organizational attitudes and behavioral mechanisms. Is felt obligation more abstract than commitment? Are there more ideas in every construct that are not disclosed in the definition? It is interesting to explore the distinctiveness between the two constructs (felt obligation and normative commitment) within the framework of the same research model, with the established research model that is based on social exchange or psychological contracts perspective. Another suggestion indicates the need for further examination about the ethical work climate dimension in the relationship with other attitudinal or behavioral outcomes. From this perspective, officers' levels of 
ethical climate can be a valuable basis for a public organization to enhance an understanding of their need for achievement to fulfill the obligation to society.

\section{REFERENCES}

Abou Hashish, E. A. (2017). Relationship between ethical work climate and nurses' perception of organizational support, commitment, job satisfaction and turnover intent. Nursing ethics, 24(2), 151-166. https://doi.org/10.1177\%2F0969733015594667.

Agarwal, J., \& Malloy, D. C. (1999). Ethical work climate dimensions in a not-for-profit organization: An empirical study. Journal of Business Ethics, 20(1), 1-14. https://doi.org/10.1023/A:1005974718602.

Allen, N. J., \& Meyer, J. P. (1996). Affective, continuance, and normative commitment to the organization: An examination of construct validity. Journal of vocational behavior, 49(3), 252-276. https://doi.org/10.1006/jvbe.1996.0043.

Arshadi, N. (2011). The relationships of perceived organizational support (POS) with organizational commitment, in-role performance, and turnover intention: Mediating role of felt obligation. Procedia-Social and Behavioral Sciences, 30. 1103-1108. https://doi.org/10.1016/j.sbspro.2011.10.215.

Aselage, J., \& Eisenberger, R. (2003). Perceived organizational support and psychological contracts: A theoretical integration. Journal of Organizational Behavior: The International Journal of Industrial, Occupational and Organizational Psychology and Behavior, 24(5), 491-509. https://doi.org/10.1002/job.211.

Blau, P. (1964). Exchange and power in social life. New York: Wiley.

Chin, W. W., \& Newsted, P. R. (1999). Structural equation modeling analysis with small samples using partial least squares. Statistical strategies for small sample research, 1(1), 307-341.

Coyle-Shapiro, J. A. M., Morrow, P. C., \& Kessler, I. (2006). Serving two organizations: Exploring the employment relationship of contracted employees. Human Resource Management: Published in Cooperation with the School of Business Administration, The University of Michigan and in alliance with the Society of Human Resources Management, 45(4), 561-583. https://doi.org/10.1002/hrm.20132.

Cropanzano, R., \& Mitchell, M. S. (2005). Social exchange theory: An interdisciplinary review. Journal of management, 31(6), 874-900. https://doi.org/10.1177\%2F0149206305279602.

Cullen, J. B., Parboteeah, K. P., \& Victor, B. (2003). The effects of ethical climates on organizational commitment: A two-study analysis. Journal of Business Ethics, 46(2), 127 141. https://doi.org/10.1023/A:1025089819456.

Dharmanegara, I. B. A., Pradesa, H. A., Tanjung, H., \& Harijanto, D. (2016). Becoming Emotionally Attached to Team: The Role of Ethical Climate Dimension in Nursing Profession. In Proceeding 15th Anniversary PDIM FEB Universitas Brawijaya International Conference (pp. 105-120). 
Eisenberger, R., Huntington, R., Hutchison, S., \& Sowa, D. (1986). Perceived organizational support. Journal of Applied psychology, 71(3), 500.

Eisenberger, R., Fasolo, P., \& Davis-LaMastro, V. (1990). Perceived organizational support and employee diligence, commitment, and innovation. Journal of applied psychology, 75(1), 5159. https://psycnet.apa.org/doi/10.1037/0021-9010.75.1.51.

Erakovich, R., \& Wyman, S. (2015). Implications of Organizational Influence on Ethical Behavior: An Analysis of the Perceptions of Public Managers. In Ethics and Integrity in Public Administration: Concepts and Cases (pp. 89-103). Routledge.

Filipova, A. A. (2007). Perceived organizational support and ethical work climates as predictors of turnover intention of licensed nurses in skilled nursing facilities. Retrieved from https://scholarworks.wmich.edu/dissertations/858/.

Filipova, A. A. (2011). Relationships among ethical climates, perceived organizational support, and intent-to-leave for licensed nurses in skilled nursing facilities. Journal of Applied Gerontology, 30(1), 44-66. https://doi.org/10.1177\%2F0733464809356546.

Fornell, C., \& Bookstein, F. L. (1982). Two structural equation models: LISREL and PLS applied to consumer exit-voice theory. Journal of Marketing research, 19(4), 440-452. https://doi.org/10.1177\%2F002224378201900406.

Gouldner, A. W. (1960). The norm of reciprocity: A preliminary statement. American sociological review, 161-178. https://doi.org/10.2307/2092623.

Huang, C. C., You, C. S., \& Tsai, M. T. (2012). A multidimensional analysis of ethical climate, job satisfaction, organizational commitment, and organizational citizenship behaviors. Nursing Ethics, 19(4), 513-529. https://doi.org/10.1177\%2F0969733011433923.

Kasekende, F., Munene, J. C., Ntayi, J. M., \& Ahiauzu, A. (2015). The interaction effect of social exchanges on the relationship between organizational climate and psychological contract. Leadership \& Organization Development Journal, 36(7), 833-848. https://doi.org/10.1108/LODJ-01-2014-0007.

Key, S. (1999). Organizational ethical culture: real or imagined?. Journal of Business Ethics, 20(3), 217-225. https://doi.org/10.1023/A:1006047421834.

Ladebo, O. J. (2006). Perceptions of organisational politics: Examination of a situational antecedent and consequences among Nigeria's extension personnel. Applied Psychology, 55(2), 255-281. https://doi.org/10.1111/j.1464-0597.2006.00230.x.

Lew, T. (2009). The relationships between perceived organizational support, felt obligation, affective organizational commitment and turnover intention of academics working with private higher educational institutions in Malaysia. European Journal of Social Sciences, 9(1), 72-87. Retrieved from http://hdl.handle.net/20.500.11937/46030.

McManus, L., \& Subramaniam, N. (2014). Organisational and professional commitment of early career accountants: do mentoring and organisational ethical climate matter?. Accounting \& Finance, 54(4), 1231-1261. https://doi.org/10.1111/acfi.12029.

Neblett, W. (1976). Feelings of obligation. Mind, 85(339), 341-350. 
Rasmussen, K., Malloy, D., \& Agarwal, J. (2003). The ethical climate of government and nonprofit organizations Implications for public-private partnerships. Public Management Review, 5(1), 83-97. https://doi.org/10.1080/1461667022000028825.

Rhoades, L., \& Eisenberger, R. (2002). Perceived organizational support: a review of the literature. Journal of applied psychology, 87(4), 698.

Sharma, J., \& Dhar, R. L. (2016). Factors influencing job performance of nursing staff: mediating role of affective commitment. Personnel Review, 45(1), 161-182. https://doi.org/10.1108/PR01-2014-0007.

Shih, C. T., \& Chen, S. J. (2011). The social dilemma perspective on psychological contract fulfilment and organizational citizenship behaviour. Management and Organization Review, 7(1), 125-151. https://doi.org/10.1111/j.1740-8784.2010.00202.x.

Schwepker Jr, C. H. (2001). Ethical climate's relationship to job satisfaction, organizational commitment, and turnover intention in the salesforce. Journal of business research, 54(1), 3952. https://doi.org/10.1016/S0148-2963(00)00125-9.

Treviño, L. K., Butterfield, K. D., \& McCabe, D. L. (1998). The ethical context in organizations: Influences on employee attitudes and behaviors. Business Ethics Quarterly, 8(3), 447-476. https://doi.org/10.2307/3857431.

Tsai, M. T., \& Huang, C. C. (2008). The relationship among ethical climate types, facets of job satisfaction, and the three components of organizational commitment: A study of nurses in Taiwan. Journal of Business Ethics, 80(3), 565-581. https://doi.org/10.1007/s10551-0079455-8.

Victor, B., \& Cullen, J. B. (1987). A theory and measure of ethical climate in organizations. Research in corporate social performance and policy, 9(1), 51-71.

Victor, B., \& Cullen, J. B. (1988). The organizational bases of ethical work climates. Administrative science quarterly, 101-125. https:// doi.org/10.2307/2392857.

Yew, L. T. (2011). Understanding the antecedents of affective organizational commitment and turnover intention of academics in Malaysia: The organizational support theory perspectives. African Journal of Business Management, 5(7), 2551-2562. https://doi.org/10.5897/AJBM10.284.

*) Hafid Aditya Pradesa, Department of Public Sector Business Administration, STIA LAN, Bandung, Indonesia (Email: hafidap85@gmail.com)

**) Joni Dawud, Department of Public Development Administration, STIA LAN, Bandung, Indonesia (Email: jonidawud @ yahoo.com)

***) Muhamad Nur Affandi, Department of Public Development Administration, STIA LAN, Bandung, Indonesia (Email: m.n.afandi@gmail.com) 